Historic, Archive Document

Do not assume content reflects current scientific knowledge, policies, or practices. 


\section{$1632 \mathrm{U}$ \\ Modifications and Evaluations of the \\ Evapotranspiration Tent}

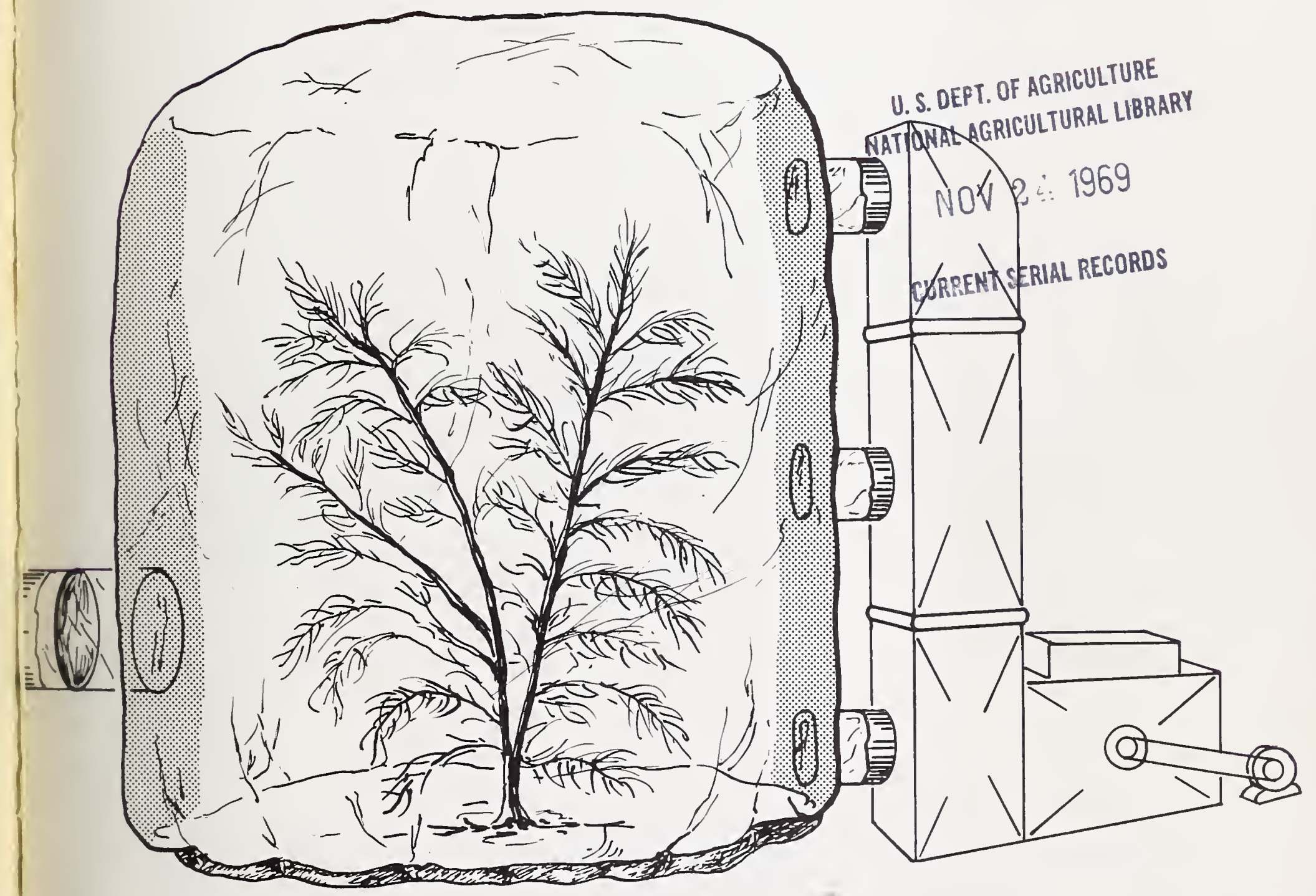

Arnett C. Mace Jr., and J.R. Thompson

Rocky Mountain Forest and Range Experiment Station Forest Service - U.S. Department of Agriculture Fort Collins, Golorado 80521 
Research Paper RM-50

Modifications and Evaluations of the Evapotranspiration Tent ${ }^{1}$ by

Arnett C. Mace, Jr., Assistant Professor ${ }^{2}$

and

J. R. Thompson, Meteorologist ${ }^{3}$

${ }^{1}$ This study was supported in part by a research grant from the U. S. Bureau of Reclamation to the Department of Watershed Management, University of Arizona, Contract No. 14-06-300-1357.

${ }^{2}$ School of Forestry, University of Minnesota, St. Paul. Mace was a Research Associate at the Department of Watershed Management, University of Arizona, Tucson, at the time this Research Paper was prepared.

${ }^{3}$ Rocky Mountain Forest and Range Experiment Station, with central headquarters maintained at Fort collins in cooperation with Colorado State University; Thompson is located at Tempe in cooperation with Arizona State University. 
$\underline{\text { Page }}$

Background . . . . . . . . . . . . . . 1

Enclosure effect . . . . . . . . . . . 1

Results and discussion . . . . . . . . . . 2

Effect of tent on radiation exchange . . . . . 2

Effect of tent on ventilation rate . . . . . 5

Ventilation rates and air temperatures of the Decker evapotranspiration tent . . . . . . . . 6

Comparison of results from tent and heat pulse measurements . . . . . . . . . . 7

Tent modifications . . . . . . . . . . . 7

Enclosure effect of the triple-inlet tent . . . . 11

Summary . • • . . . . . . . . . . . . . 15

Literature cited . . . . . . . . . . . 15 


\title{
Modifications and Evaluations of the Evapotranspiration Tent
}

\author{
Arnett C. Mace, Jr. and J. R. Thompson
}

\section{Background}

Evapotranspiration is one of the fundamental components of the hydrologic cycle. In the South and Southwest, where water shortage is critical and evapotranspiration may account for as much as 95 percent of the water loss, both administrative and research organizations have become increasingly concerned with modifying vegetation to reduce evapotranspiration. To manipulate vegetation to increase water supply it is necessary to make an accurate estimate of evapotranspiration losses by different cover types under different climatic and hydrologic conditions. Numerous theoretical and empirical methods are used to estimate water lost through the evapotranspiration process. However, these methods are based on assumptions or empirical coefficients that are not applicable, or at least not without significant sources of error.

Decker et al. (1962) were the first to develop a large inflatable plastic "tent" to measure evapotranspiration rates of large shrubs and small trees. Ventilated enclosures such as the evapotranspiration tent provide one of the most practical approaches for evapotranspiration measurements since the device is portable, inexpensive, and the plant remains in its "natural" state. The tent method has been criticized, however, due to its interference with the natural environment surrounding the enclosed plant (Lee 1966).

\section{Enclosure Effect}

Decker et al. (1962) surmised that enclosed plots would reduce evapotranspiration rates, but would not yield exaggerated estimates of comparative water loss by tamarisk. The reduction of actual rates would thus minimize rather than magnify differences between different cover types. Decker concluded that "Although enclosure effect could not create serious difficulty in the primary use for which the technique was intended, analysis and evaluation of it would enable one to compute rates for unenclosed plots and would thus extend the usefulness of the technique." In several exploratory studies, Decker found no completely satisfactory method of accurately measuring the enclosure effect. He measured a 22 percent reduction in transpiration rates for potted tamarisk plants in the enclosure as a first approximation.

Lee (1966) severely criticized the tent as designed by Decker et al. (1962) on the basis of enclosure effect. Lee's measurements of enclosure effects on potted plants indicated a relative increase in transpiration rates of 2 to 70 percent in the tent, with definite strata and niches present. These results are opposite to those obtained by Decker. However, Lee (1966) indicated that soil moisture was not measured, but kept near field capacity. Small differences in soil moisture under high atmospheric vapor pressure deficits and root distribution could account for his large variations (Gardner 1960). He also ascertained that leaf stomata were closed on all plants sampled during mid-day periods when the enclosure effect was measured. This indicates perhaps that water was being lost only as cuticular transpiration, since the soil surface was sealed. Lee (1966) concluded that:

1. Absolute vaporization rates in the tent-enclosed space may vary considerably from those in the open.

2. Aside from differing physiological reactions to environmental changes among plant species, vegetation types may react differently if they occupy different strata in the tent.

3. Expected differential enclosure effects rule out the use of the tent, with present design, to determine even the relative water consumption among cover types. 
4. With proper design modifications, and simultaneous monitoring of environmental parameters within and outside of the enclosure, a tent system might provide reasonably accurate estimates of water loss rates; but other techniques are usually more satisfactory and less expensive.

5. The tent technique's potential lies in the study of processes where it is desired to have a controlled or known environment, but should not be used to obtain estimates of actual or relative evapotranspiration from wildlands.

Shachori et al. (1962) described an adaptation of the "Decker tent" to measure evapotranspiration rates of maqui-shrub cover types in Israel. Evaluation of enclosure effects indicate temperatures were $1.0^{\circ}$ to $1.5^{\circ} \mathrm{C}$. higher in the enclosure than outside, and the variation within the tent was less than $1.0^{\circ} \mathrm{C}$. They also reported a 2.5 percent insignificant increase in transpiration rates inside the tent by weighing potted plants.

Further evaluation of the enclosure effect by Shachori ef al. (1966) indicates a total possible positive error of $11.5 \pm 9.5$ percent. Seven \pm 4.0 percent was attributed to enclosure effect and $4.5 \pm 4.0$ percent to humidity and airflow measurements.

\section{Results and Discussion}

In a study of evapotranspiration losses from flood plain vegetation conducted by the University of Arizona on the Gila River and Salt Creek; a branch of the Gila, it became apparent that an artificial microclimate was created by the evapotranspiration tent designed by Decker et al. (1962). Mesquite and tamarisk trees were defoliated after being enclosed for an 8-hour period on May 18, 1964, and June 16, 1964, respectively. This indicated a serious enclosure effect and the internal microclimate in the tent was therefore evaluated.

Reports of a diversity of plant transpiration responses to environmental variation are numerous (Daubenmire 1959, Kozlowski 1964). Contrasting root, anatomical, and physiological systems of major plant groups such as xerophytes, mesophytes, and halophytes contribute to the variations in responses to environmental fluctuations. Variation within a group or species is not accurately known because of phenological variation. For these reasons, a physical rather than biological evaluation of the tent enclosure effect was made.

This evaluation is based upon (1) field work on the Gila River carried out by the senior author with the cooperation of the junior author in a study of evapotranspiration of tamarisk, supported in part by the U. S. Bureau of Reclamation, and (2) laboratory tests carried out jointly by the authors both at the University of Arizona, Tucson, and at the Forest Hydrology Laboratory, Tempe.

\section{Effect of Tent on \\ Radiation Exchange}

The microclimate surrounding a plant, and the sources of energy for biological processes, surface heating, and vaporization, are dependent on the magnitude of the various components of the energy balance equation presented in simplified form as follows (Rose 1966):

$R_{S}(1-\alpha)=R_{L}+G+H+L E$

where:

$R_{S}=$ flux density of total short-wave radiation

$\alpha=$ albedo or reflection coefficient of plant or ground surface;

$R_{L}=$ net flux density long-wave radiation emitted by the surface, the difference between that emitted and absorbed;

$G=$ heat flux density into the soil;

$H=$ sensible heat flux density into the atmosphere;

$L=$ latent heat of vaporization of water; and,

$E$ = evaporation rate.

The difference between the incoming and outgoing components of equation [1] is the net radiation flux:

$R_{N}=R_{S}(1-\alpha)-R_{L}$

Combining equations [ 1 ] and [2], $R_{N}$ is equivalent to:

$R_{N}=G+H+L E$

A measure of the enclosure effect on transpiration rates may be demonstrated by measurement of $R_{N}$ of equation [3]. Total and net radiation were 
neasured over enclosed and unenclosed tamarisk Jlants with two all-wave radiometers (Suomi and 'uhn 1957), as modified by Goodell (1962), which lave an accuracy of \pm 4 percent. Total radiation Jver a tamarisk canopy in the tent was reduced 10.6 percent, while net radiation was increased by 2.1 percent (fig. 1). Measurements over bare soil

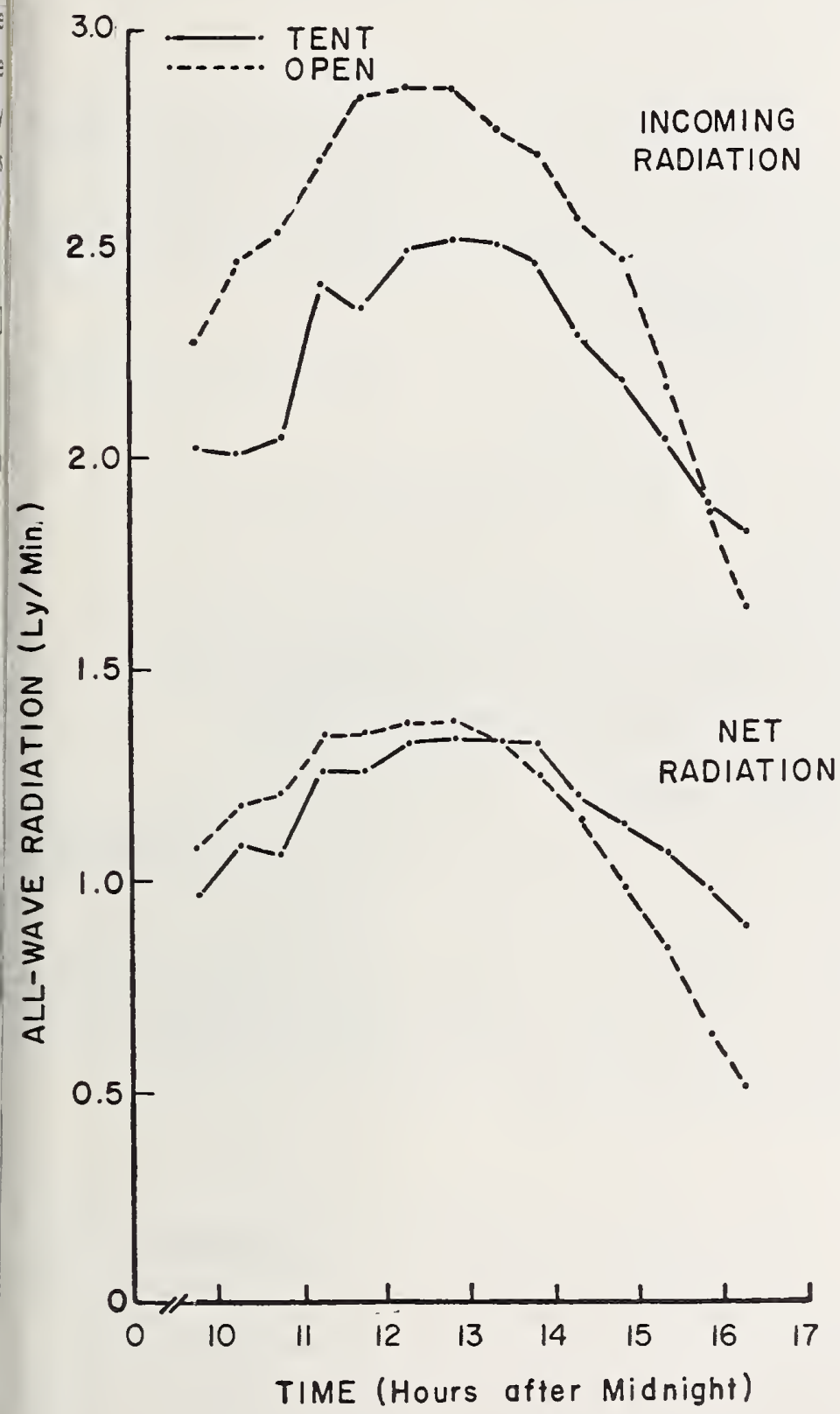

Figure 1.--All-wave incoming and net radiation of an enclosed and an inenclosed tomarisk plot. Reduction in incoming radiation averaged 10.6 percent while net radiation increased by 2.1 percent.

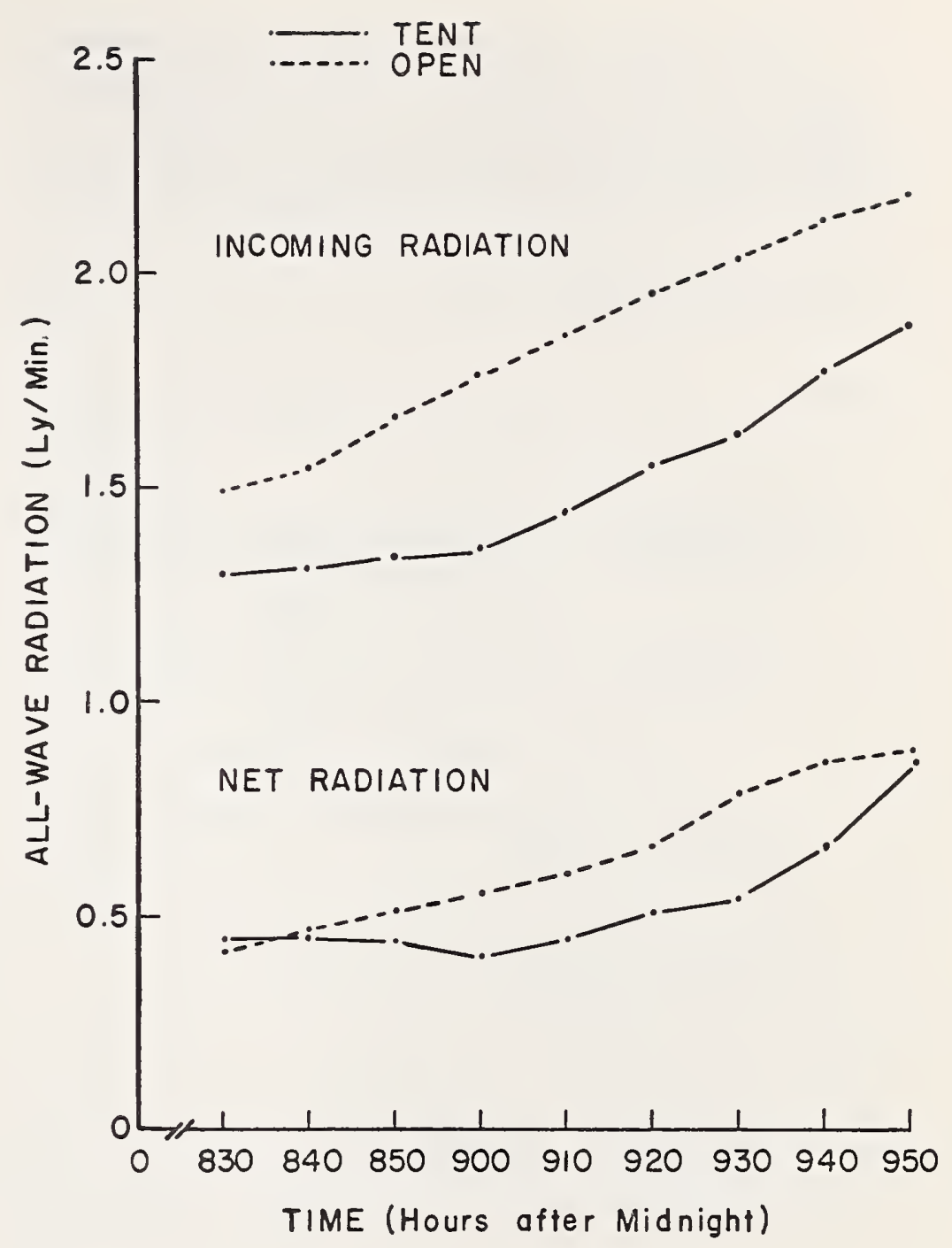

Figure 2.--All-wave incoming and net radiation of an enclosed and an unenclosed bare soil plot. Mean incoming and net radiation were reduced 19.5 and 17.8 percent, respectively. indicated reductions in incoming and net radiation of 19.5 and 17.8 percent, respectively, inside the tent (fig. 2). The differential reduction can be attributed to the difference in albedo of tamarisk and bare soil, and the distribution of energy in the tent.

According to Businger (1963), the "greenhouse effect" (increase in temperature by trapping of long-wave radiation) is of minor importance compared to the increase in temperature resulting from a lack of ventilation. He showed that 22 percent of the temperature increase in a glasshouse could be attributed to the "greenhouse effect," while 78 percent was ascribed to the lack of ventilation. 
Net radiation was theoretically compared under completely transparent and 4-mil polyvinyl plastic, used for the tent, with transmissivities of 0.90 and 0.25 for short- and long-wave radiation, respectively:

$R_{N}=R_{S}(1-\alpha)+\sum R_{a}-R_{b}$

where:

$R_{N}=$ net radiation ( $1 \mathrm{y} / \mathrm{min}$.); $\begin{aligned} \mathrm{R}_{\mathrm{S}}= & \text { scattered and direct beam solar radiation } \\ & (\text { ( } y / \text { min. }) ;\end{aligned}$

$R_{a}=$ Tong-wave radiation from the atmosphere (7y/min.);

$\mathrm{R}_{\mathrm{b}}=$ long-wave back radiation ( $\left.\mathrm{y} / \mathrm{min}.\right)$;

$\alpha=$ albedo for solar radiation assumed 0.15 for plant cover;

$\Sigma=$ absorbtivity $=$ emissivity $=.95$

$R_{a}=\sigma T_{a}^{4}(a+b \sqrt{e})$;

$R_{b}=\sum \sigma T_{s}^{4}$; and

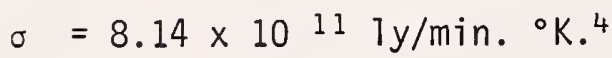

It was assumed that:

$R_{S}=1.20 \mathrm{Ty} / \mathrm{min} . ;$

$T_{a}=T_{s}=310^{\circ} \mathrm{K} . ;$ and

e $=9 \mathrm{mb}$.

where:

$\mathrm{T}_{\mathrm{a}}=$ temperature of ambient air $\left({ }^{\circ} \mathrm{K}.\right)$;

$\mathrm{T}_{\mathrm{S}}=$ temperature of crown canopy $\left({ }^{\circ} \mathrm{K}.\right)$; and

e = vapor pressure (mb.).

The assumed values are similar to those measured in the field.

A climatological estimate of $R_{a}$ was made by means of Brunt's (1932) equation, with constants of $a=0.605$ and $b=0.048$ as follows:

$R_{a}=\sigma T_{a}^{4}(a+b \sqrt{e})=0.5637 y / m i n$.
Lee (1966) computed $R_{a}$ by means of Swinbank's (1963) equation, which gave a value of 0.653 $\mathrm{ly} / \mathrm{min}$. Sellers (1965) pointed out that Swinbank's equation does not yield favorable results in the southwestern United States. He indicated that the failure is due to singular dependence on temperature.

Net radiation for a completely transparent tent from equation [4] for $R_{S}=1.20 \mathrm{ly} / \mathrm{min}$. is:

$R_{N}=0.8407 \mathrm{y} / \mathrm{min}$.

For a plastic cover with transmissivities of 0.90 and 0.25 for short- and long-wave radiation, respectively, two sources of incoming long-wave radiation are present, the atmosphere and the plastic, and $\mathrm{R}_{\mathrm{a}}$ becomes:

$R_{a}=0.25\left(\sigma T_{a}^{4}(a+b \sqrt{e})+\sum \sigma_{v} T_{v}^{4}\right)$

where:

$\Sigma_{V}=$ emmissivity of plastic layer; and

$T_{v}=$ temperature of plastic layer.

$\mathrm{R}_{\mathrm{N}}$ then becomes:

$R_{N}=0.90 R_{S}(1-\alpha)+R_{a}+0.75 \sigma T_{V}{ }^{4}-0.95 \sigma T_{S}{ }^{4}$

$R_{N}=0.90 R_{s}(1-\alpha)+R_{a}-0.20 \sigma T_{v, s}{ }^{4}$

$R_{N}=0.90(1.020)+0.25(0.563)-(0.20)(0.714 ;$

$R_{N}=0.916 \mathrm{ly} / \mathrm{min}$.

The "greenhouse effect" is the difference between 0.916 and $0.840 \mathrm{ly} / \mathrm{min}$., or $0.076 \mathrm{ly} / \mathrm{min}$. Net radiation is theoretically shown to increase inside the tent with transmissivities of 0.90 and 0.25 for short- and long-wave radiation. Figure 1 indicates that net radiation inside the tent is greater than in the opening in the late afternoon. This increase can be attributed to the increase in incoming long-wave radiation from the tent due to an increase in temperature as shown in equation [4]. Lee (1966) indicated that net radiation in the tent varied by \pm 15 percent from measurements in the 
open during mid-day periods. The magnitude of variation between net radiation in the tent and open will depend on temperature and the shortwave radiation reduction. Astemperature increases, the contribution of long-wave radiation to incoming radiation increases. The reduction of short-wave radiation is dependent on the age and cleanliness of the polyvinyl tent material. The increase in temperature associated with the long-wave blocking effect is shown in the following computations:

$\begin{aligned} \text { Volume of air in tent }= & 2.55 \times 10^{7} \mathrm{~cm} .{ }^{3} \\ \text { Air replaced in tent }= & 1.72 \text { times } / \mathrm{min} . \\ \text { Effective volume/minute }= & 2.55 \times 10^{7} \mathrm{~cm} .{ }^{3} \\ & \times 1.72 / \mathrm{min}=4.386 \\ & \times 10^{7} \mathrm{~cm} .3 / \mathrm{min} . \\ \text { Specific heat of air }= & 0.24 \mathrm{cal} . / \mathrm{gm} . /{ }^{\circ} \mathrm{C} ., \\ & \text { or } 2.64 \times 10^{-4} \mathrm{cal} . / \\ & \mathrm{cm} .3 /{ }^{\circ} \mathrm{C} .\end{aligned}$

The energy available is $0.076 \mathrm{ly} / \mathrm{min}$. received on a surface of $88,288 \mathrm{~cm}^{2}$, or 6,710 calories per minute. Assuming this energy is used for sensible heat, the calories needed to raise and maintain the temperature of the tent $1^{\circ} \mathrm{C}$. above inlet temperature is:

$4.386 \times 10^{7} \mathrm{~cm} \cdot{ }^{3} / \mathrm{min}$.

$\times 2.64 \times 10^{-4} \mathrm{cal} . / \mathrm{cm} \cdot{ }^{3} /{ }^{\circ} \mathrm{C}$.

$=11.58 \times 10^{3} \mathrm{cal} . /^{\circ} \mathrm{C}$ - min.;

and the temperature increase in the tent is:

$6.710 \times 10^{3} \mathrm{cal} . / \mathrm{min} . \div 1.158$

x $10^{4} \mathrm{cal} . /^{\circ} \mathrm{C}-\min .=0.58^{\circ} \mathrm{C}=1.04^{\circ} \mathrm{F}$.

At a temperature of $45^{\circ} \mathrm{C}$. $\left(113^{\circ} \mathrm{F}\right.$.) the blocking effect is equivalent to $0.186 \mathrm{ly} / \mathrm{min}$., which could increase the temperature of the enclosure $1.42^{\circ} \mathrm{C}$. $\left(3.55^{\circ} \mathrm{F}.\right)$
Effect of Tent on Ventilation Rate

If $0.076 \mathrm{ly} / \mathrm{min}$. is assumed to be the sensible heat flux due to ventilation, the increase in temperature due to lack of ventilation of the enclosure can be shown by Businger's (1963) equation:

$g \ell H_{\text {ven }}=c_{a i} \frac{V}{A_{w}} S\left(t_{j}-t_{0}\right)$

where:

$\begin{aligned} g \ell H_{\text {ven }}= & \text { sensible heat flux retained in tent } \\ & \text { due to inadequate ventilation }\end{aligned}$ ( ly/min.);

$\mathrm{C}_{\mathrm{ai}}=$ volumetric heat capacity (ca)./cm. $\left.{ }^{3}{ }^{\circ} \mathrm{C}.\right)$;

$\mathrm{V}=$ volume of tent $\left(\mathrm{cm} \cdot{ }^{3}\right)$;

$A_{W} \quad=$ wall surface $\left(\mathrm{cm} \cdot{ }^{2}\right)$;

$\mathrm{S}=$ number of times fresh air volume replaced per minute $\left(\min ^{-1}\right)$;

$t_{i}=$ air temperature inside;

$t_{0}=$ air temperature outside; and

$\begin{aligned}\left(t_{i}-t_{0}\right)= & \text { mean temperature difference between } \\ & \text { inside and outside air }\left({ }^{\circ} \mathrm{C} .\right) .\end{aligned}$

Then:

$.076 \mathrm{ly} / \mathrm{min} .=$

$$
\begin{aligned}
& \left(2.64 \times 10^{-4} \mathrm{cal} . / \mathrm{cm}^{3}{ }^{3}{ }^{\circ} \mathrm{C} .\right) \frac{2.55 \times 10^{7} \mathrm{~cm}^{3}}{4.09 \times 10^{5} \mathrm{~cm} . .^{2}}\left(1.72 \mathrm{~min}^{-1}\right) \\
& x\left(t_{j}-t_{0}\right)=.028 \mathrm{cal} . / \mathrm{cm} .{ }^{2} \mathrm{~min} .-{ }^{\circ} \mathrm{C} .\left(t_{i}-t_{0}\right) ;
\end{aligned}
$$

therefore:

$$
\left(t_{i}-t_{0}\right)=2.71^{\circ} \mathrm{C} \text {, or } 4.87^{\circ} \mathrm{F} .
$$

If the sensible heat flux due to a lack of adequate ventilation is $0.186 \mathrm{ly} / \mathrm{min}$, the temperature increase is $6.64^{\circ} \mathrm{C}$., or $11.75^{\circ} \mathrm{F}$. at $45^{\circ} \mathrm{C}$. $\left(113.0^{\circ} \mathrm{F}\right.$.). These calculations indicate that the reduced ventilation rate of the enclosure $\left(4.87^{\circ} \mathrm{F}\right.$.) causes a more significant internal energy increase than the "greenhouse effect" (1.04 ${ }^{\circ} \mathrm{F}$.).

These calculations are based on isothermal conditions, which usually do not occur. The long-wave "greenhouse effect" under nonisothermal conditions may be obtained by the expression: 
$R_{g}=\left[R_{a} \Sigma-R_{L}\right]_{i}-\left[R_{a} \Sigma-R_{L}\right]_{0}$

where:

$R_{g}=$ long-wave "greenhouse effect";

$i=$ inside enclosure; and

0 = outside enclosure.

Then:

$$
\begin{aligned}
R_{g}= & {\left[0.25 \sigma T_{a}^{4}(a+b \sqrt{e})+\Sigma_{v} \sigma T_{v}{ }^{4}-\Sigma \sigma T_{s}{ }^{4}\right]_{i} } \\
& -\left[\sigma T_{a}^{4}(a+b \sqrt{e})-\Sigma \sigma T_{s}^{4}\right]_{0} \\
R_{g}= & -0.75 \sigma T_{a}^{4}(a+b \sqrt{e})+\Sigma_{v} \sigma T_{v}{ }^{4} \\
& +\Sigma \sigma T_{s_{0}}^{4}-\Sigma \sigma T_{s_{i}}{ }^{4}
\end{aligned}
$$

Equation [7] indicates that the magnitude of $R_{g}$ under nonisothermal conditions depends on the temperature of the tent $\left(T_{v}\right)$ and the crown canopy $\left(T_{S_{j}}\right)$, which are opposite in sign. On a clear day, cariopy temperature should exceed the tent plastic temperature $\left(T_{v}\right)$, and the value of $R_{g}$ computed for isothermal conditions would be the upper limit of the blocking effect. On a cloudy day or during low radiation intensities, $T_{S_{i}}$ will be reduced inside the enclosure, and $R_{g}$ will increase as a function of the difference:

$$
\Sigma_{v} \sigma T_{v}^{4}-\Sigma \sigma T_{S}
$$

\section{Ventilation Rates and Air Temperatures of the Decker Evapotranspiration Tent}

Air introduced by means of portable blowers at speeds of 1,400 to 1,900 ft./min. through an 8 -inch inlet resulted in an average air velocity of 6 to $8 \mathrm{ft} . / \mathrm{min}$. through the tent. Air movement inside the enclosure was traced with a jeweled anemometer (activation velocity of $1.76 \mathrm{ft}$. $/ \mathrm{min}$.). The anemometer was activated only near the inlet, outlet, and in the area of the flow pattern as shown in figure 3. Measurements of air temperatures inside the enclosure indicated definite areas of increased temperatures which were associated with low air velocities. The maximum increase was $25.0^{\circ} \mathrm{F}$. above ambient conditions.

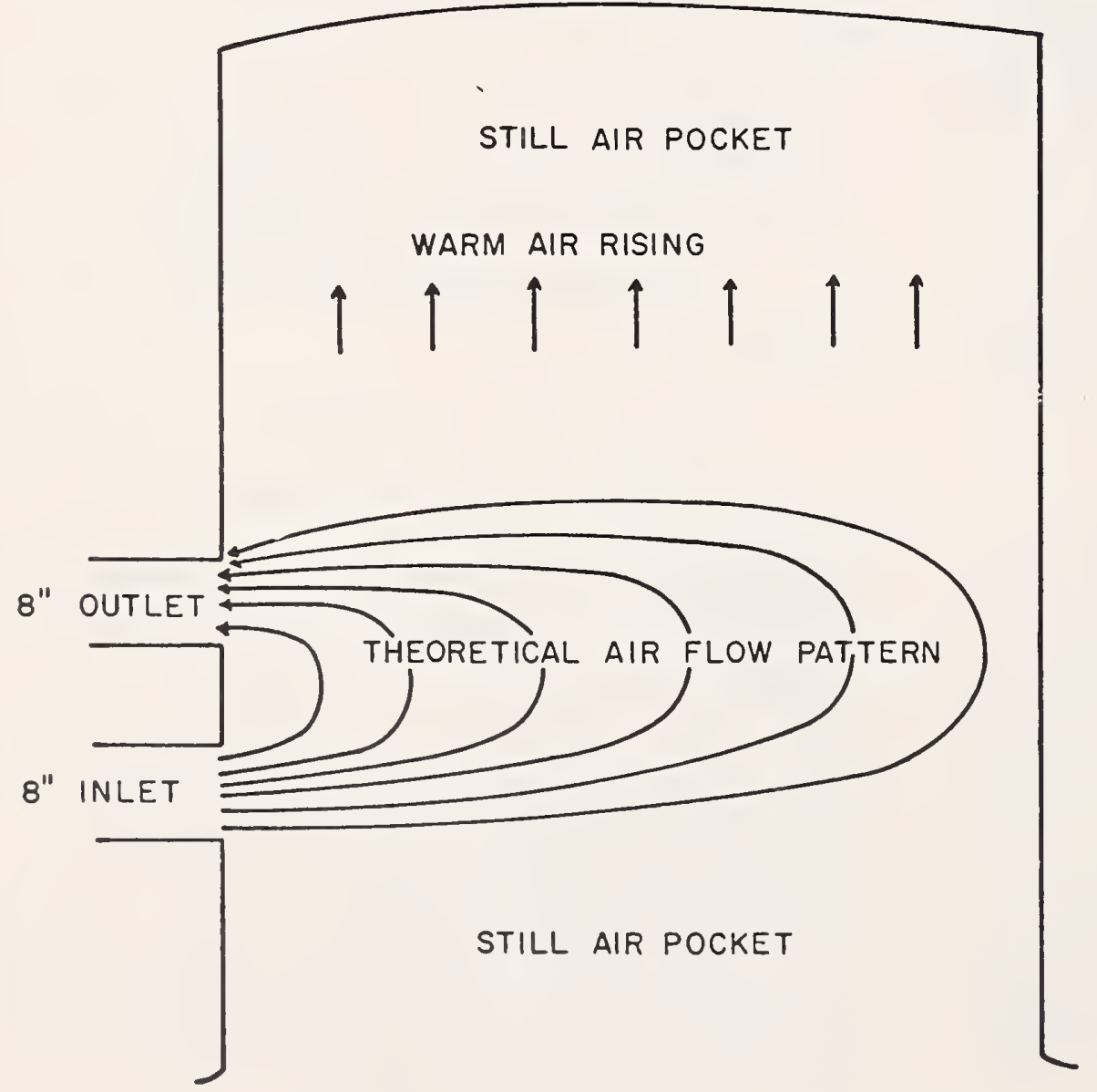

Figure 3.--Air circulation pattern of "Decker evapotranspiration tent," showing heat trapping and still air pockets. 
Comparison of Results

from Tent and Heat

Pulse Measurements

Decker and Skau (1964) reported a good correlation for coniferous species between heat pulse velocity (sap flow velocity) and transpiration rates determined with the tent technique. Skau and Swanson (1963) showed that heat pulse velocity is clasely correlated with water forced through stem sections. Field experiments conducted by these authors indicated a close response between heat pulse velocity and environmental variables such as shading, leaf wetting, irrigation, and natural soil drying.

Swanson's (1962) instrument was used to detect the nature of the enclosure effect on the tamarisk plants. According to Swanson, this technique should be valid for obtaining an index of sap flow rates in tamarisk.

Measurements made on tamarisk plants on Salt Creek where the water table depth was 30 feet indicated a significant increase in sap flow velocities inside the enclosure compared to plants outside (fig. 4). Similar measurements on the Gila River site where the water table depth was 3 feet also indicated a significant increase in sap flow velo-

Figure 4.--Heat pulse velocities of an enciosed and an unenclosed tamarisk plant growing on an area in which the water table depth was 30 feet. cities inside the tent (fig. 5), but the enclosure effect was less pronounced on the moist site.

\section{Tent Modifications}

The Salt Creek and Gila River data indicated that the evapotranspiration tent as designed by Decker et al. (1962) was inadequate for measuring evapotranspiration rates of tamarisk plants because of enclosure effects. Design changes were made, therefore, in an attempt to eliminate heat trapping in the upper portion of the tent (fig. 6). No attempt was made to reduce the radiation "greenhouse effect" since it is relatively small compared to the effect of reduced ventilation rates. Also, the difficulty of keeping the tent material clean and dry in the field prevents a natural radiation exchange.
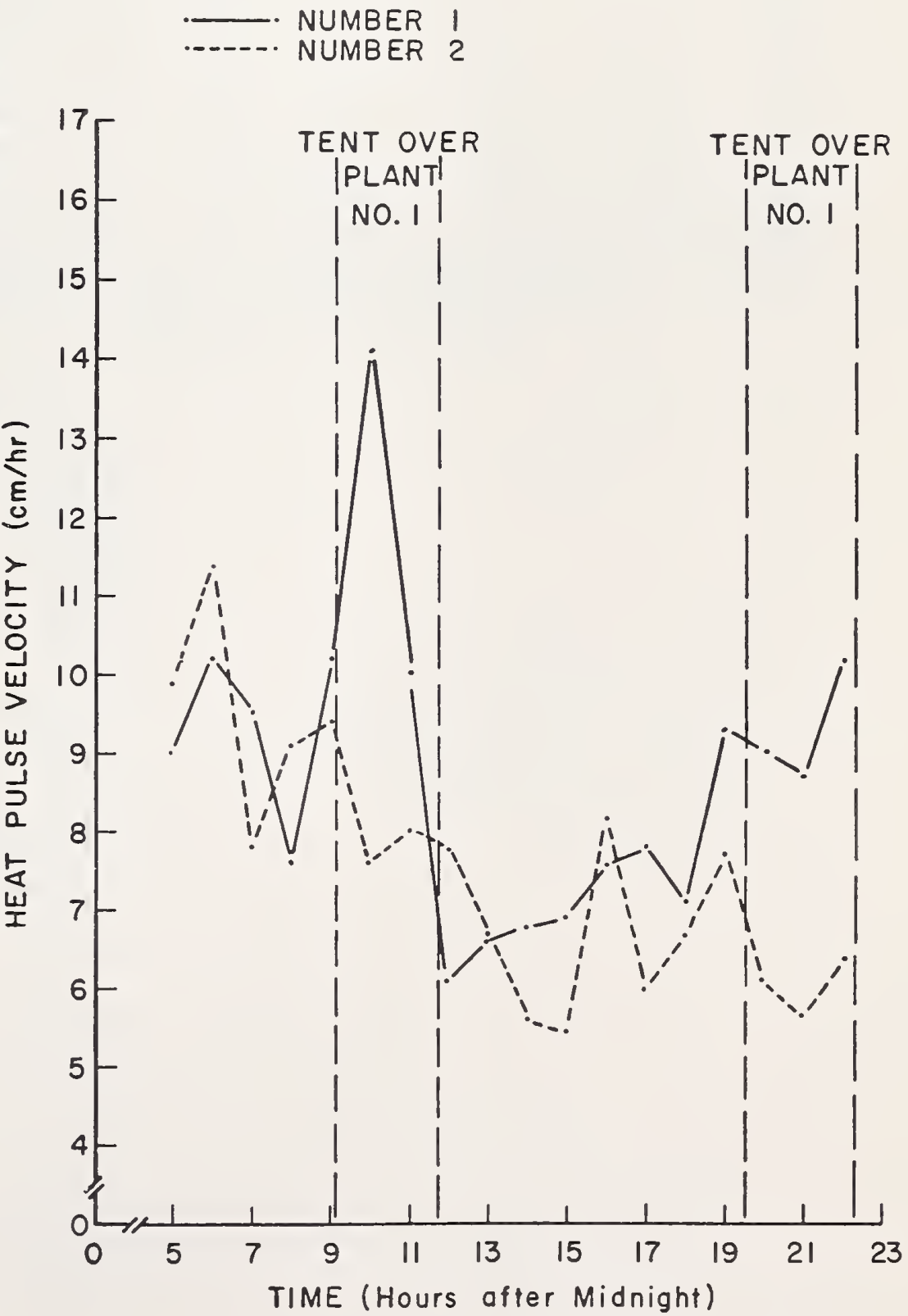
Air temperature was measured and flow patterns were determined with smoke bombs in the redesigned tent. Figure 7 indicates that the temperature buildup was still present with this design. Tests conducted to determine airflow patterns demonstrated a pattern similar to that in figure 6 .

A second design with a triple inlet (fig. 8) achieved more desirable airflow patterns and ventilation rates to reduce the long-wave blocking effect. Smoke bombs placed at the inlet demonstrated airflow patterns similar to the theoretical pattern shown in figure 9.
Air was introduced by means of a squirrel-cage blower through three 10 -inch inlets located at heights of 2, 6, and 9 feet above the ground surface. A square metal extension ( $1.2 \mathrm{ft} .2$ in area) conducted air from the blower to the upper inlets. The blower was run by a 3/4-horsepower electric motor. This ventilating assembly had a capacity of 2,900 $\mathrm{ft} .3 / \mathrm{min}$. compared to the blower of Decker et al. (1962) which had a capacity of $547 \mathrm{ft}^{3} / \mathrm{min}$. Polyvinyl perforated sleeves extending the height of the tent were attached at the inlet and outlet to obtain a more uniform airflow patternat all heights.

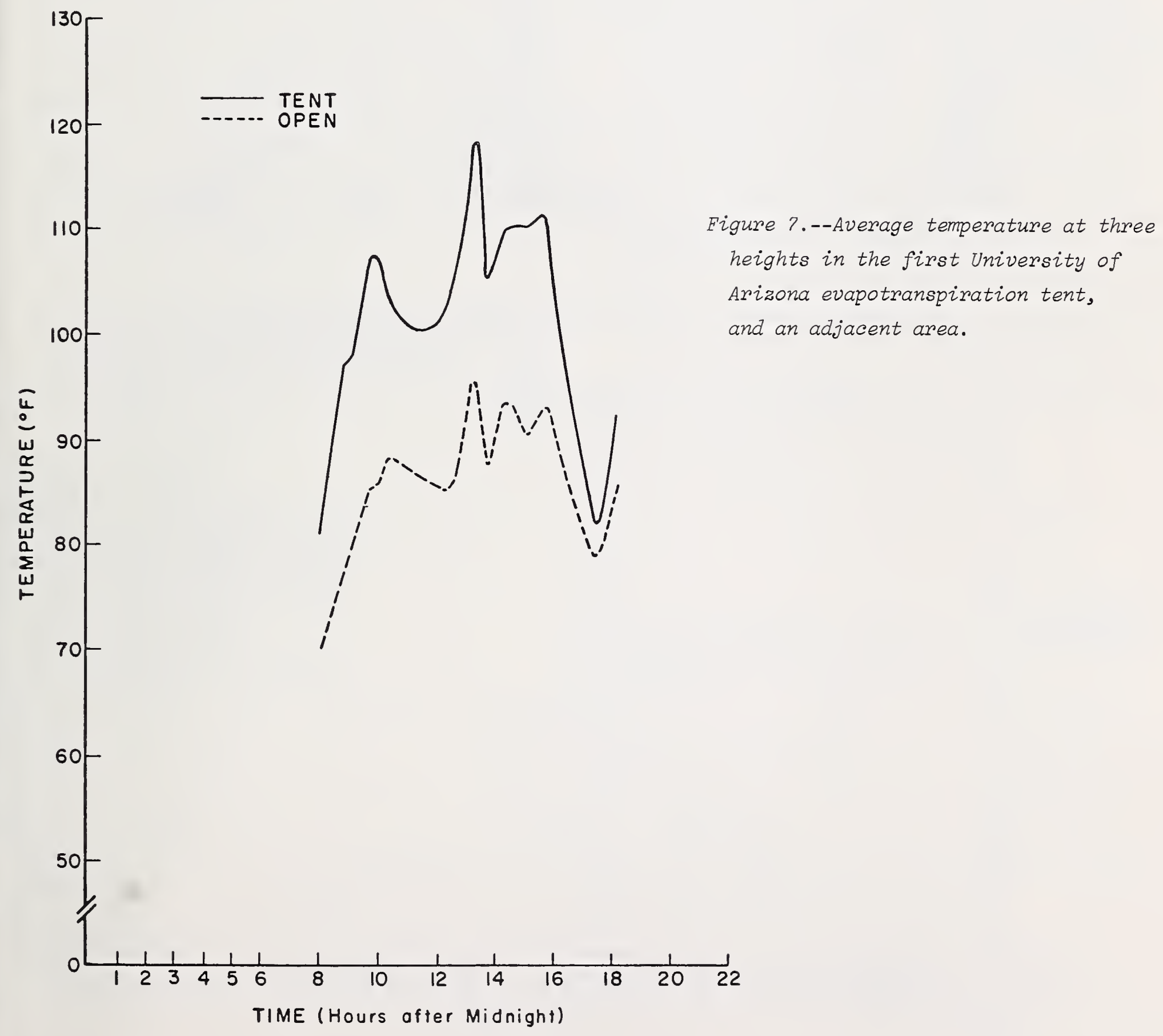




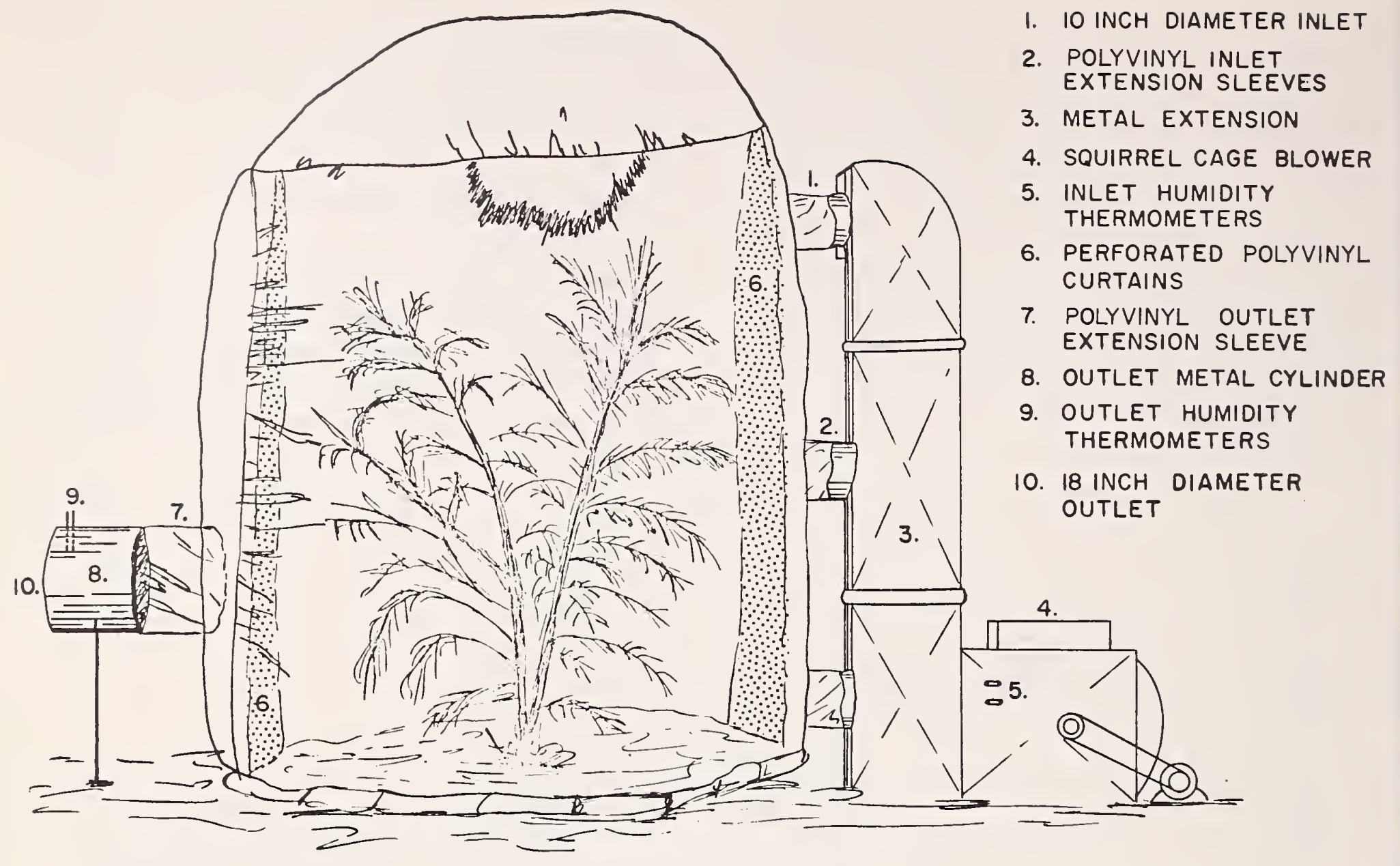

Figure 8.--Diagram of triple-inlet evapotranspiration tent.

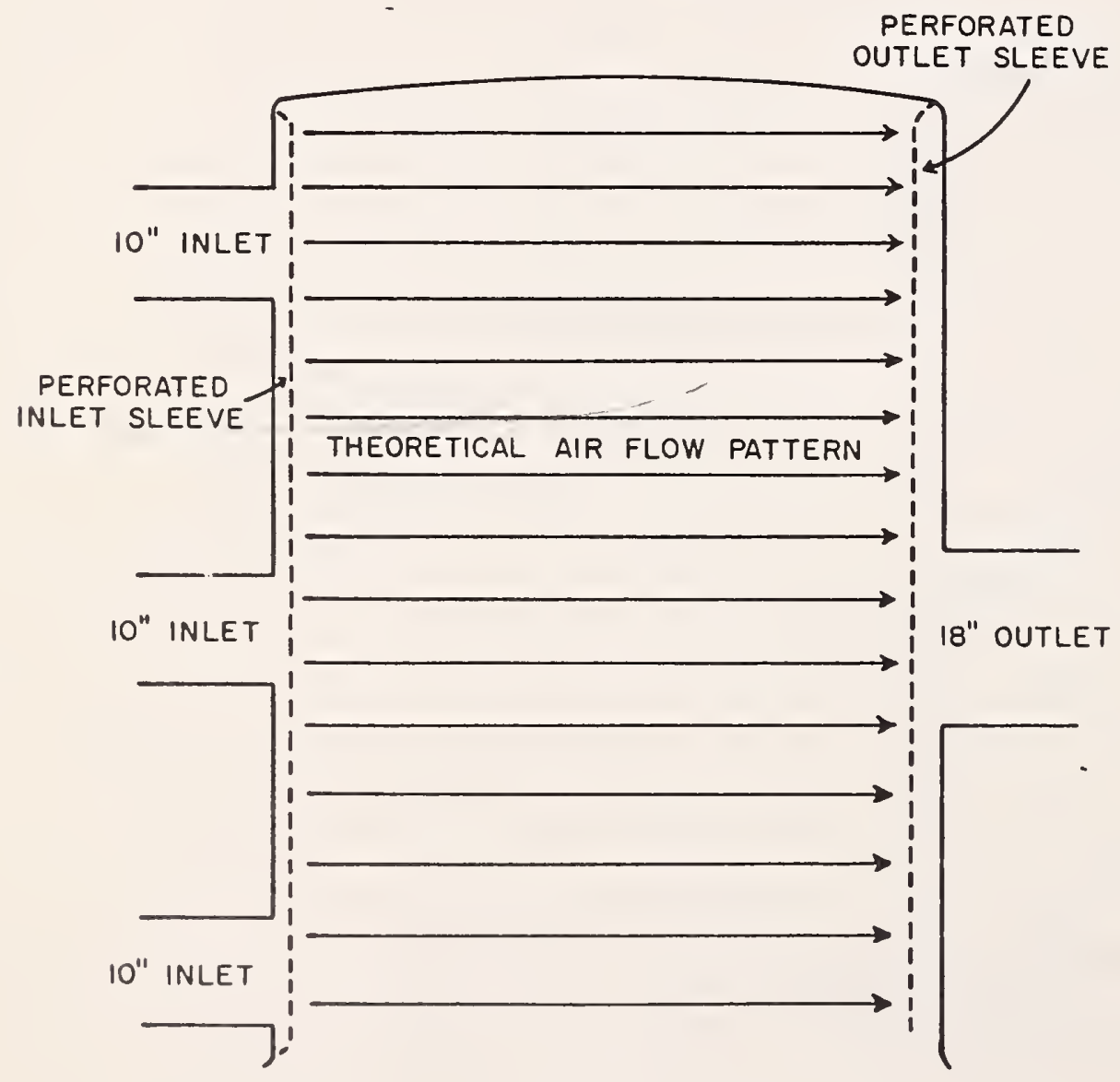

Figure 9.--Air circulation pattern of the tripleinlet evapotranspiration tent. The stizz air pockets were eliminated. 


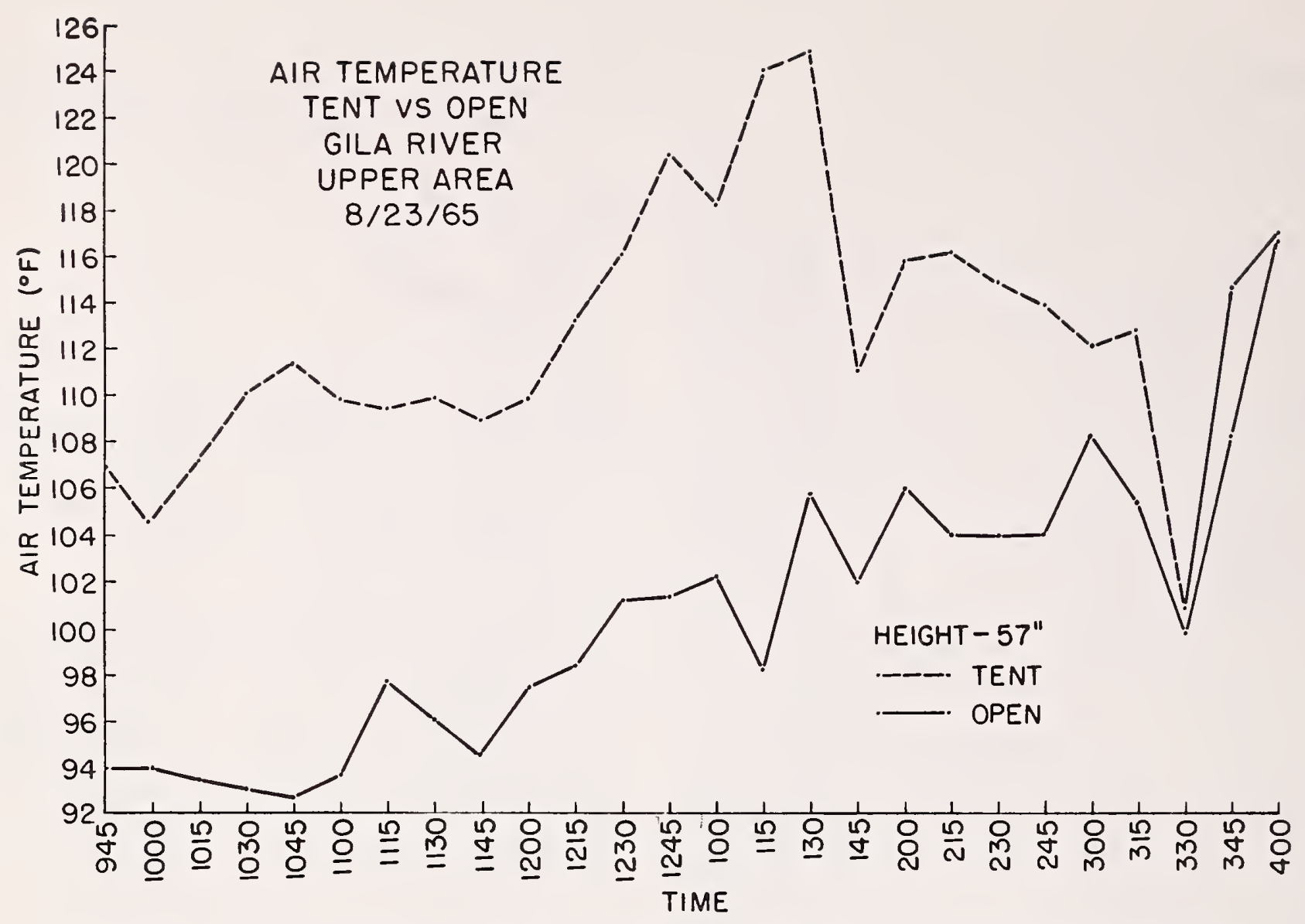

Figure 11.--Air temperatures in a tamarisk canopy at a height of 57 inches inside and outside the tent when the tree occupies only half the volume of the tent. The tent was removed at 3:10 p.m.

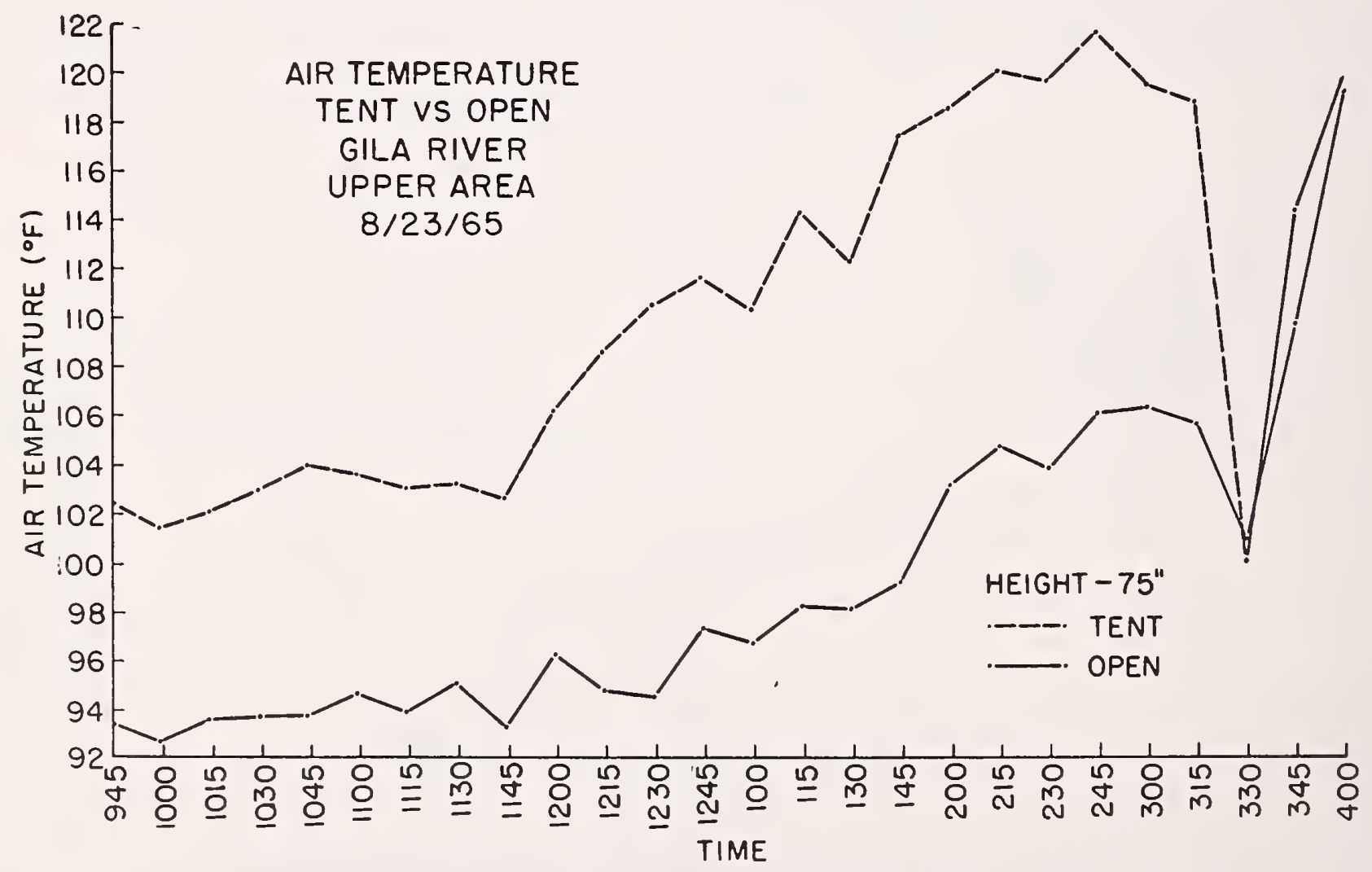

Figure 12.--Air temperatures in a tamarisk canopy at a height of 75 inches inside and outside the tent when the tree occupies only half the volume of the tent. The tent was removed at 3:10 p.m. 


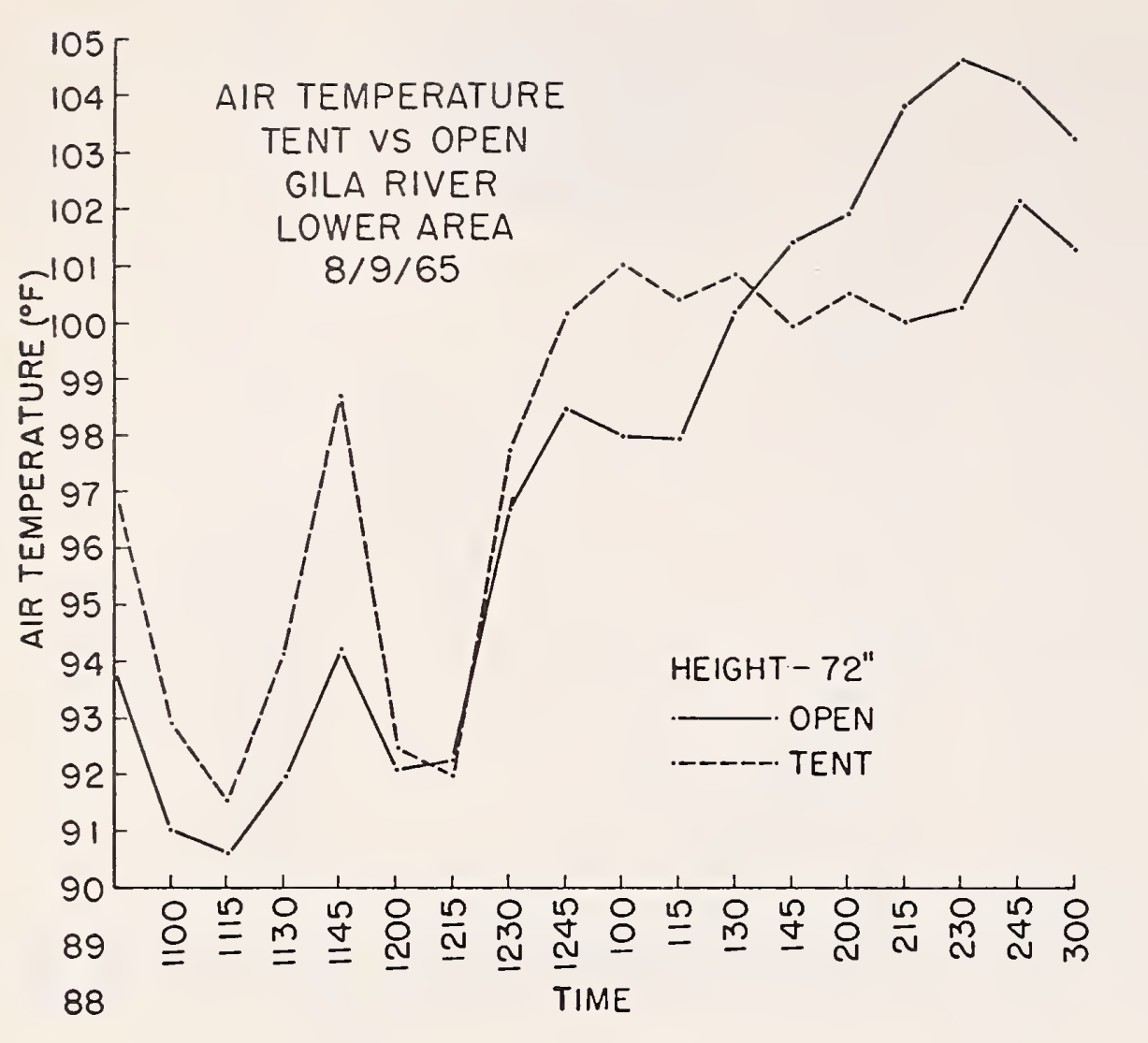

Figure 15.--Air temperatures in a tamarisk canopy at a height of 72 inches inside and outside the tent when the tree occupies the entire volume of the tent. The tent was removed at 2:00 p.m.

found to be very critical, wet-bulb thermometers were calibrated in the laboratory before tent runs.

Six additional calibration runs were made over an evaporation pan with the triple-inlet tent (table 1). The water level change during a run was measured outside the tent by an electrical

Table 1.--Comparison of the measured water-level change of an evaporation pan and computed evaporation rate by tent method

\begin{tabular}{c|c|c|c}
\hline $\begin{array}{c}\text { Run } \\
\text { number }\end{array}$ & $\begin{array}{c}\text { Length } \\
\text { of } \\
\text { run }\end{array}$ & $\begin{array}{c}\text { Measured } \\
\text { water-leve1 } \\
\text { change }\end{array}$ & $\begin{array}{c}\text { Computed } \\
\text { evaporation } \\
\text { rate }\end{array}$ \\
\hline & Hours & - - Inch per hour - - \\
1 & 2.0 & 0.020 & 0.033 \\
2 & 2.5 & .040 & .067 \\
3 & 3.0 & .020 & .041 \\
4 & 3.5 & .030 & .041 \\
5 & 5.0 & .010 & .016 \\
6 & 5.0 & .020 & .033 \\
\hline
\end{tabular}

point gage and modified $\mathrm{FW}-1$ recorder 5 in a stilling well. The $\mathrm{FW}_{-1}$ gear ratio was altered from the standard full-scale pen travel of 1 foot to a scale of 0.05 foot, thus allowing an accurate reading of 0.0005 foot.

These data indicate that the evaporation rate computed from the tent overestimates the water loss measured in an evaporation pan. Some of the possible sources and magnitudes of this systematic error are:

1. An inaccurate measurement of either the wet-or dry-bulb temperature at the inlet or outlet. An error of $\pm 0.1^{\circ} \mathrm{F}$. in the dry-bulb reading at the inlet, at a dry-bulb temperature of $98.4^{\circ} \mathrm{F}$., would cause a calculated change in the evaporation rate of \pm 0.0006 inch per hour (table 2).

No significant variation in temperature was measured due to variation in measurement position within the inlet and outlet. However, variations with time were greater than variation by position in the inlet or outlet--as much as $3.6^{\circ} \mathrm{F}$. change in the wet-bulb temperature in 5 minutes. Such variation may suggest that temperatures

${ }^{5}$ Trade nomes and company names are used for the benefit of the reader, and do not imply endorsement or preferential treatment. by the U.S. Department of Agriculture. 
Table 2.--Accuracy of transpiration rates in relation to errors in temperature measurements

\begin{tabular}{|c|c|c|c|c|}
\hline \multicolumn{2}{|c|}{$\begin{array}{c}\text { Inlet } \\
\text { temperature }\end{array}$} & \multicolumn{2}{|c|}{$\begin{array}{c}\text { Outlet } \\
\text { temperature }\end{array}$} & \multirow{2}{*}{$\begin{array}{l}\text { Error in } \\
\text { transpiration } \\
\text { rate }\end{array}$} \\
\hline $\begin{array}{l}\text { Dry } \\
\text { bulb }\end{array}$ & $\begin{array}{l}\text { Wet } \\
\text { bulb }\end{array}$ & $\begin{array}{l}\text { Dry } \\
\text { bulb }\end{array}$ & $\begin{array}{l}\text { Wet } \\
\text { bulb }\end{array}$ & \\
\hline - & - Degr & $S F$. & - & Inch per hour \\
\hline \pm 0.1 & -- & -- & -- & \pm 0.0006 \\
\hline \pm .2 & -- & -- & -- & \pm .0012 \\
\hline-- & \pm 0.1 & -- & -- & \pm .0025 \\
\hline-- & \pm .2 & -- & -- & \pm .0050 \\
\hline-- & -- & \pm 0.1 & - & \pm .0006 \\
\hline-- & -- & \pm .2 & -- & \pm .0012 \\
\hline-- & -- & -- & \pm 0.1 & \pm .0025 \\
\hline-- & -- & -- & \pm .2 & \pm .0050 \\
\hline
\end{tabular}

should be recorded continuously, but this could reduce portability. The error in sampling this parameter would be random, however, rather than systematic.

2. Air-velocity measurements at the center of the outlet varied between 1,550 and 1,650 feet per minute. An error of \pm 50 feet per minute in air velocity would lead to a possible error of \pm 0.0002 inch per hour in evapotranspiration rate determinations. Measurements made at the center of the outlet do not represent the average velocity of the air moving through the outlet. Velocity measurements made at 41 points in the 18-inch outlet indicated that the averagevelocity was 0.834 times that measured at the center of the outlet. Sebenik ${ }^{4}$ indicated that the measured velocity at the center of the outlet should be multiplied by a factor of 0.83521 . All evapotranspiration values were reduced by the factor of 0.834 .

3. Atmospheric pressure is included in calculations of absolute humidity at the inlet and outlet. Atmospheric pressure was $2 \mathrm{~mm}$. Hg higher inside the tent. An error of $\pm 100 \mathrm{~mm} . \mathrm{Hg}$ at $93^{\circ} \mathrm{F}$. would affect the evapotranspiration rate by only \pm 0.001 inch per hour, therefore, errors in measurement of atmospheric pressure were considered insignificant.

\section{Summary}

The original plastic evapotranspiration tent has been shown to alter the enclosed microenvironment by (1) reducing solar radiation, (2) reducing wind movement, and (3) trapping terrestrial radiation. Evidence indicates that reduced ventilation rate is the principal cause of the change in the microclimate. After the tent was modified to increase wind movement, data indicated no significant increase in air temperature within the enclosure as long as it was fully occupied by vegetation.

Calibration of the tent over a paved surface and over plastic showed close agreement between inlet and outlet humidities. Calibration over a water tank showed fair agreement between inside and outside tank evaporation, but evaporation computed by tent techniques exceeded measured waterlevel change. Measurements indicate this source of error may be attributed to inadequate instrumentation for determining average wind velocity at the outlet.

With future modifications that incorporate a variable tent size and improved wind velocity measurements, a plastic tent could provide a reliable means of estimating evapotranspiration from plants in their natural environment.

\section{Literature Cited}

Brunt, D.

1932. Notes on radiation in the atmosphere.

Quart. J. Roy. Meteorol. Soc. 58: 389-420. Businger, J. A.

1963. The glasshouse (greenhouse) climate. 382 pp. In Physics of Plant Environment. W.R. van Wijk, Ed. Amsterdam: North Holland Publishing Co.

Daubenmire, R. F.

1959. Plants and environment. 442 pp. New York: John Wiley and Sons, Inc.

Decker, John P., Gaylor, William G., and Cole, Frank D.

1962. Measuring transpiration of undisturbed tamarisk shrubs. Plant Physiol. 37: 393-397. Decker, J. P., and Skau, C. M.

1964. Simultaneous studies of transpiration rate and sap velocity in trees. Plant Physiol. 39: 213-215. 
Gardner, W. R.

1960. Dynamic aspects of water availability to plants. Soil Sci. 89: 63-73.

Goodell, Bertram C.

1962. An inexpensive totalizer of solar and thermal radiation. J. Geophys. Res. 67: 13831387.

\section{Kozlowski, T. T.}

1964. Water metabolism in plants. 227 pp. New York: Harper and Row.

\section{Lee, Richard.}

1966. Effect of tent type enclosures on the microclimate and vaporization of plant cover. Oecologia Planatarum (Gauthier Villars) Paris, 1: 301-326.

Rose, C. W.

1966. Agricultural physics. 226 pp. London: Pergamon Press.

Sellers, William D.

1965. Physical climatology. 272 pp. Chicago: Univ. Chicago Press.

Shachori, A. Y., Stanhill, G., and Michaeli, A.

1962. The application of integrated research approach to the study of effects of different cover types on rainfall disposition in the Carmel Mountains, Israel. 77 pp. Symp. on Methodology of Plant Eco-physiology, UNESCO Arid-Zone Program, Institut de Botanique, Montpellier, France. Stanhill, G., and Rosenzweig, D.

1966. Study of difference in effects of forest and other vegetative covers on water yield. 21 pp. Annu. Rep. No. 2, Soil Erosion Res. Sta., Rupin Inst. of Agr. Emek Heter, Israel. Skau, C., M., and Swanson, R. H.

1963. An improved heat pulse velocity meter as an indicator of sap speed and transpiration. J. Geophys. Res. 68: 4743-4749.

Suomi, V. E., and Kuhn, P. M.

1956. An economic radiometer. Tellus 23: 1-6. Swanson, Robert $\mathrm{H}$.

1962. An instrument for detecting sap movement in woody plants. U. S. Forest Serv., Rocky Mountain Forest and Range Exp. Sta. Sta. Pap. 68, 16 pp.

Swinbank, W. C.

1963. Longwave radiation from clear skies. Quart. J. Roy. Meteorol. Soc. 89: 339-348. 


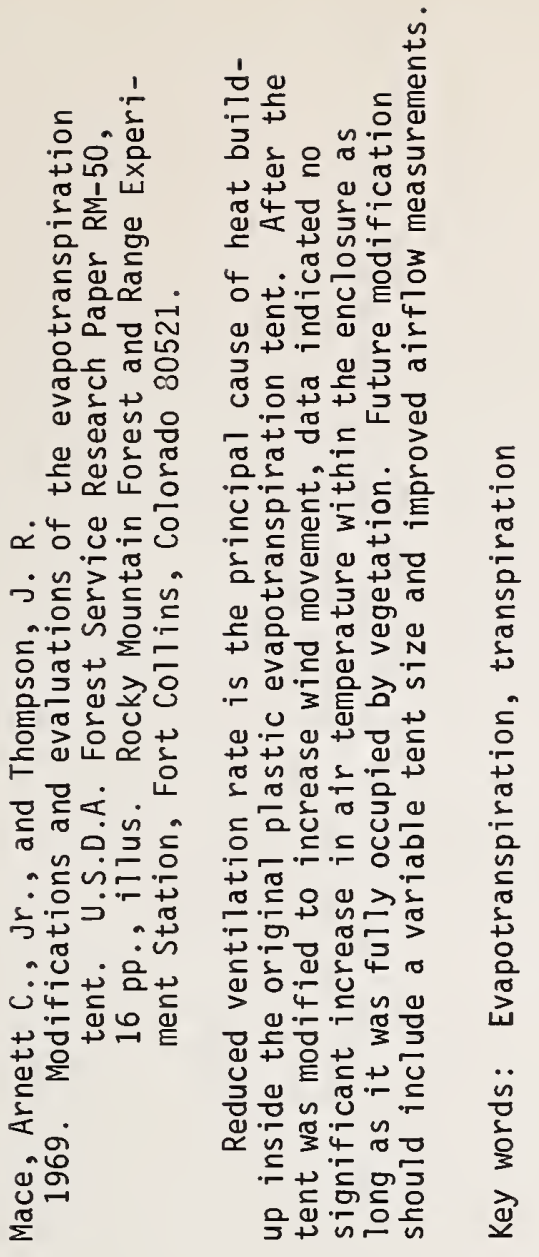

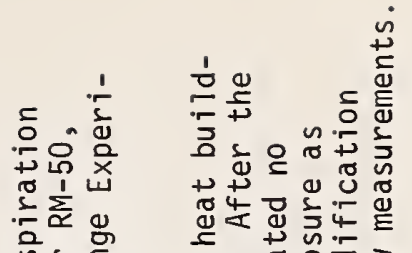

는 동

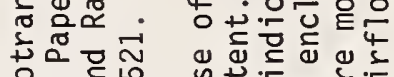

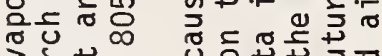

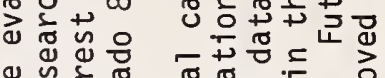

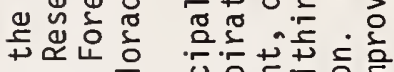

$x^{4} 40.50$

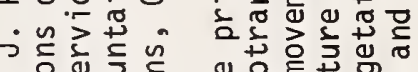

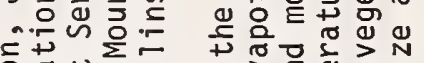

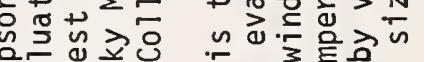

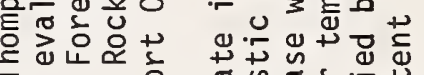

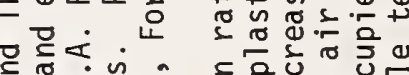

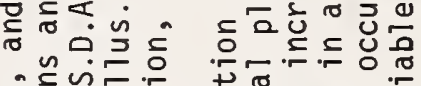

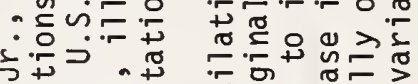

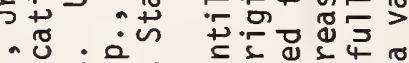

ن.

萧

Q

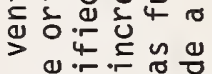

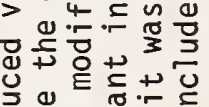

安。

ษัำ

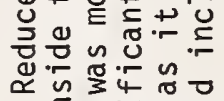

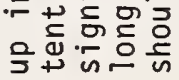

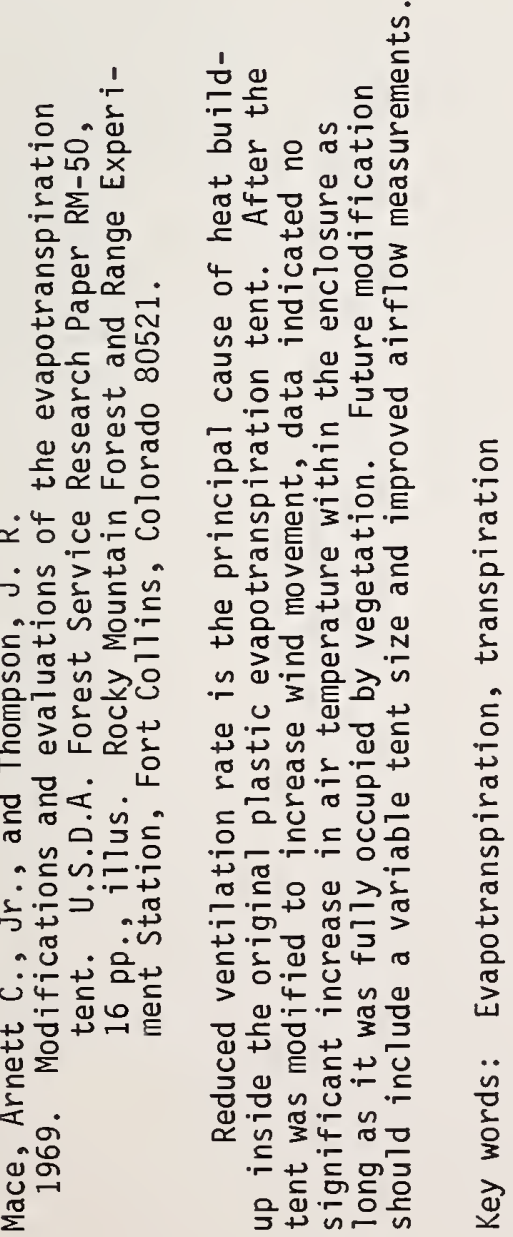

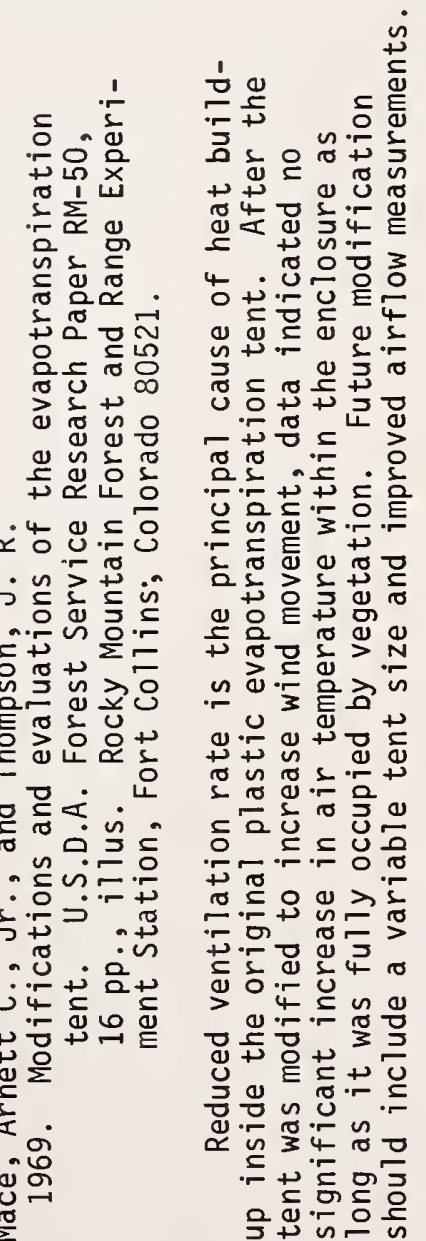

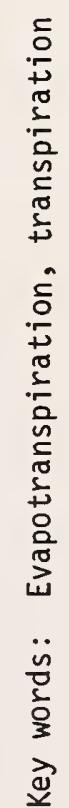




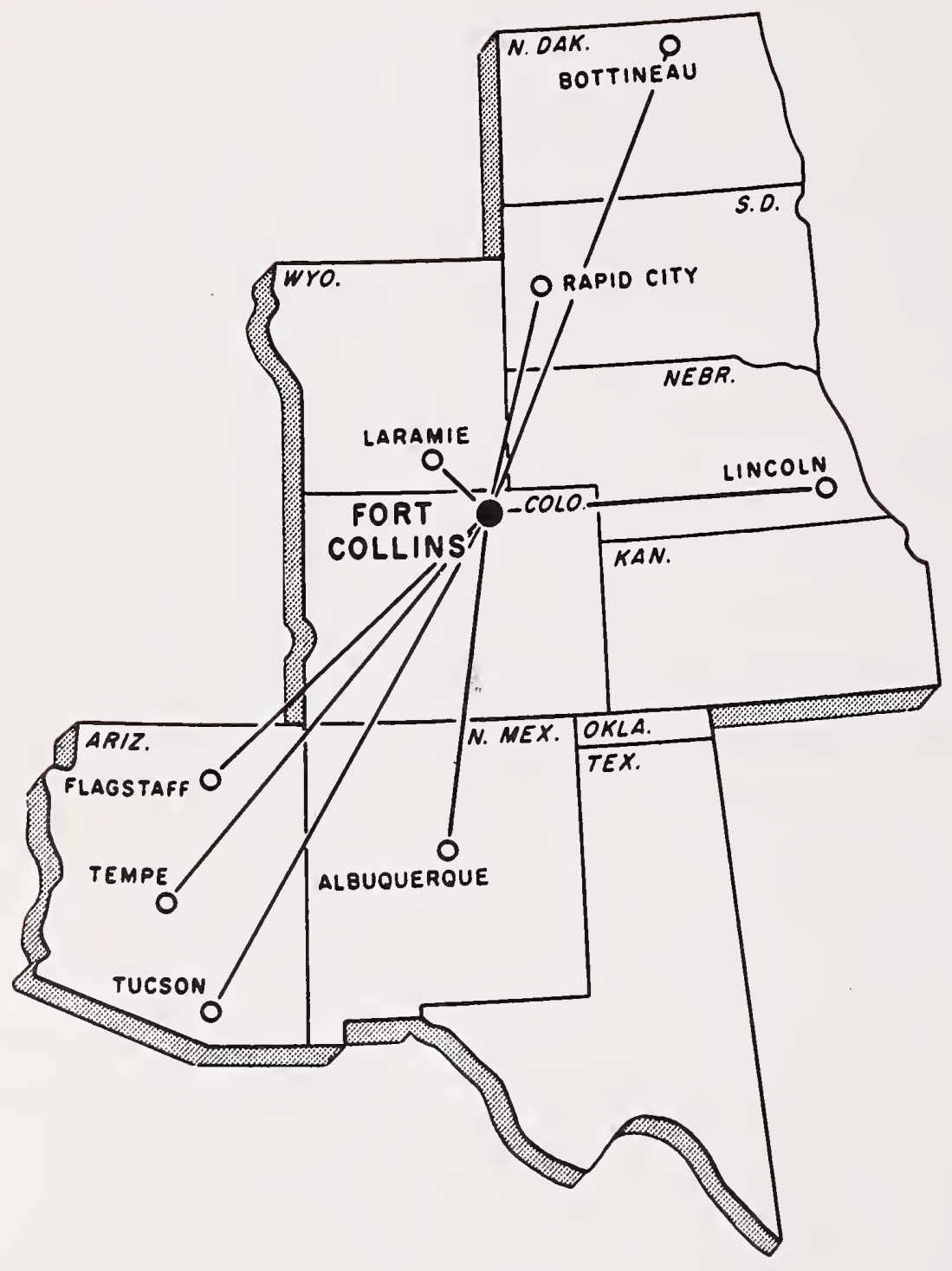

